\title{
KAJIAN PERLINDUNGAN IMPLEMENTASI HAK ASASI MANUSIA BAGI NARAPIDANA PEREMPUAN
}

\section{Fiqih Bagus Aryo Seno ${ }^{1,}$ Padmono Wibowo²}

1Prodi Manajemen Pemasyarakatan,Politeknik Ilmu Pemasyarakatan, email: Fiqihbagus8@gmail.com ${ }^{2}$ Prodi Manajemen Pemasyarakatan,Politeknik Ilmu Pemasyarakatan

\section{ABSTRAK}

Lembaga Pemasyarakatan Perempuan sejatinya harus
mengimplementasikan hak narapidana perempuan tersebut yang sesuai
dengan peraturan perundang - undangan. Implementasi perlindungan HAM
narapidana perempuan dapat dilihat dari berbagai aspek hak yang sudah
diterima oleh narapidana dan yang sudah diterapkan oleh pihak Lembaga
Pemasyarakatan, tentunya dengan dukungan sarana dan prasarana yang
baik. Penelitian di Lapas Perempuan klas IIA Jakarata Timur dengan
menggunakan metode pendekatan historis (Historical Approach)
menghasilkan bahwa Implementasi perlindungan HAM narapidana
perempuan belum berjalan secara optimal. Ada lima aspek dari 12 aspek
kriteria yang perlu mendapatkan perhatian khusus.

\section{PENDAHULUAN}

Di Indonesia ada begitu banyak peraturan bahkan lembaga perlindungan hak asasi manusia sejak pemerintah Indonesia meratifikasi berbagai instrumen HAM internasional seperti Universal Declaration of Human Rights (UDHR) pada tahun 1948 serta menerbitkan Undang-Undang HAM (Undang - Undang Nomor 39 Tahun 1999), Undang undang Peradilan HAM (Undang - Undang Nomor 26 Tahun 2000), dan juga peratutan lain yang bersumber dari UUD 1945 dan Undang - Undang HAM. Namun walaupun semakin banyak peraturan perundang-undangan HAM yang dibentuk oleh pemerintah Indonesia khususnya para legislator sebagai wakil rakyat kadang kala implemetasinya tidak selaras dengan aturan yang ada, dimana dari penerapannya HAM seringkali

\section{Kata Kunci: \\ Perlindungan \\ narapidana; Hak Asasi \\ Manusia; Narapidana \\ Perempuan \\ Cite this paper: \\ Fiqih Bagus Aryo Seno, \\ P. W., 2020. Kajian \\ Perlindungan \\ Implementasi Hak \\ Asasi Manusia Bagi \\ Narapidana \\ Perempuan. Widya \\ Yuridika: Jurnal Hukum, \\ 3(2).}


dikesampingkan apalagi seseorang yang berhadapan dengan hukum atau yang sementara dan yang sedang menjalani masa pidananya di Lembaga Pemasyarakatan ${ }^{1}$

Sejalan dengan UUD 1945, Pancasila sebagai dasar negara di dalam Sila Ke-2 yang berbunyi "Kemanusiaan Yang Adil Dan Beradab" menjamin bahwa manusia Indonesia diperlakukan secara beradab meskipun berstatus narapidana.dan pada Sila Ke-5 berbunyi||keadilan sosial bagi seluruh rakyat Indonesia dimaksudkan agar narapidana diberi kesempatan untuk bisa berinteraksi dan juga bersosialisasi layaknya seorang manusia normal lainya. narapidana memang merupakan seseorang yang telah melanggar HAM orang lain, namun bukan berarti HAM yang melekat pada dirinya dengan serta merta hilang dan dia boleh diperlakukan semena-mena oleh pihak lain guna menebus semua perbuatan jahatnya.

Dalam Undang-undang Nomor 12 Tahun 1995 pasal 2 menyebutkan bahwa, "sistem pemasyarakatan diselenggarakan dalam rangka membentuk warga binaan pemasyarakatan agar meniadi manusia yang seutuhnya, menyadari kesalahan, memperbaiki diri dan tidak mengulang tindak pidana sehingga dapat diteima kembali oleh lingkungan masyarakat dapat aktif berperan dalam pembangunan, dan dapat hidup secara wajar sebagai warga yang baik dan bertanggung iawab". 2

Pada kenyataannya walaupun mantan narapldana tersebut telah menjalani masa pembinaannya di Lembaga Pemasyarakatan (Lapas), banyak masyarakat yang masih menganggap bahwa mantan narapidana adalah kelompok masyarakat yang harus dihindari, diwaspadai bahkan djasingkan dari pergaulan masyarakat, sehingga mereka cenderung sulit untuk bersosialisasi. Misalnya saja pada saat mereka rnencari pekerjaan di luar, kendatipun di dalam lapas mereka telah dibekali dergan keterampilan. Tetapi hal tersebut menjadi sia-sia karena mereka telah dikenal melalui identitasnya yang buruk. Hal lni jugalah yang menjadi salah satu penyebab tidak sedikit yang akhirnya justru mengulangi perbuatan jahatnya, atau lazim disebut residivis (petrus, 1995). Dibutuhkan sebuah tindakan untuk memberikan hak yang layak bagi narapidana untuk tetap mampu belajar dan bersosialisasi dengan baik setelah menjalani masa hukuman didalam Lapas.

Pada dasarnya setiap orang mempunyai hak untuk mengembangkan diri untuk kepentingan dirinya sendiri, dimana hak ini merupakan hak asasi setiap individu, tidak terkecuali bagi orang-orang yang sedang tercabut kebebasannya, yaitu narapidana yang sedang menjalani pidana di dalam Lembaga Pemasyarakatan. Hak pengembangan diri juqa dapat dikatakan sebagai hak konstitusional karena telah dijamin oleh UUD '1945 dan diperkuat lagi oleh UU No. 39 Tahun 1999 tentang HAM pasal 28 C ayat I UUD Negara Republik lndonesia Tahun 1945. Demikian halnya narapidana perempuan yang dimaksud, walaupun mereka merupakan warga negara lndonesia (WNI) yang hilang kemerdekaannya karena menjalani masa pidana dalam Lembaga Pemasyarakatan, namun mereka harus tetap diperlakukan sesuai dengan aturan yang berlaku dan tidak melanggar Hak Asasi Manusia (HAM).

Oleh karena itu ${ }^{3}$ dalam Undang - Undang No. 12 tahun 1995 pasal 14 secara tegas dinyatakan bahwa narapidana berhak atas beberapa hal, yaitu: 1) melakukan ibadah sesuai agama atau kepercayaannya; 2) mendapatkan perawatan baik rohani maupun

\footnotetext{
${ }^{1}$ Undang - undang nomor 39 tahun 1999 tentang hak asasi manusia bab 1 memuat ketentuan umum

2 http://hukum.unsrat.ac.id/uu/uu_12_95.htm

${ }^{3}$ Undang - Undang Nomor 12 thn 1995 tentang pemasyarakatan pasal 14 memuat aspek hak - hak narapidana
} 
jasmani; 3) mendapatkan pendidikan dan pengajaran; 4) mendapatkan pelayanan kesehatan dan makanan yang layak; 5) menyampaikan keluhan; 6) mendapatkan bahan bacaan dan mengikuti siaran media massa lainnya yang tidak dilarang; 7) mendapatkan upah atau premi atas pekerjaan yang dilakukan; 8) menerima kunjungan keluarga, penasihat hukum, atau orang tertentu lainnya; 9) mendapatkan pengurangan masa pidana; 10) mendapatkan kesempatan berasimilasi, termasuk cuti mengunjungi keluarga; 11) mendapatkan pembebasan bersyarat; 12) mendapatkan cuti menjelang bebas dan; 13) mendapatkan hak - hak narapidana sesuai dengan peraturan perundang - undangan yang berlaku.

Pada dasarnya hak dan kewajiban antara narapidana perempuan dan narapidana pria adalah sama seperti yang dipaparkan pada Peraturan Pemerintah Republik Indonesia Nomor 32 Tahun 1999 Bab 2. Hanya saja dalam konteks tertentu, narapidana perempuan berhak mendapatkan beberapa perlakuan khusus dibandingkan narapidana pria, oleh karena itu mereka berbeda dalam beberapa hal diantaranya karena perempuan mernpunyai kodrat yang tidak dipunyai oleh narapidana pria seperti menstruasi. hamil, melahirkan. dan menyusui. Oleh karena itu, dalam hal ini hak-hak narapidana perempuan perlu mendapat perhatian yang khusus baik menurut Undang - undang maupun oleh petugas Lembaga Pemasyarakatan di seluruh wilayah Indonesia (Suparji, 2011).

Berdasarkan keterangan Kepala Rutan Wanita Pondok bambu bahwa, kendala terbesar yang dihadapi oleh pihak Rutan adalah sangat terbatasnya daya larnpung, diikibatkan tidak proposionalnya antara jumlah tahanan yang masuk dan yang keluar, dimana jumlah tahanan yang masuk seringkali lebih banyak dari pada jumlah yang keluar, sehingga menyebabkan kondisi overcrowded. Kondisi inilah yang menjadi stimulan terjadinya beberapa penyimpangan di lingkungan Rutan ataupun Lapas. Pada contohnya; ${ }^{4}$ Seorang narapidana perempuan berinisial CAM (30), melarikan diri dari Rumah Tahanan (Rutan) Lhok Nga, Aceh Besar. Kepala cabang Rutan Lhok Nga, Eko yulianto mengatakan, "CAM melarikan diri setelah djberi izin komandan regu jaga, muhammad Yusuf tanpa sepengetahuan dirinya. Alasan CAM keluar adalah untuk menjenguk orang tua yang sakit". (www.tempo.com). Lalu di Yogyakarta seorang narapidana berinisial DRS mencoba kabur saat di kembalikan ke LP Wanita Wirogunan usai persidangan yang dilaksanakan di Pengadilan Negeri Wonorsari. (www.tribunnews.com).

Narapidana yang ditempatkan di Lembaga Pemasyarakatan tentu tidak hanya menjalani masa pidana secara fisik misalnya makanan yang dijatah, tetapi juga pidana secara psikologis seperti hilangnya kebebasan individu, kasih sayang dari anak atau pasangan. Pidana secara psikologis merupakan beban terberat bagi setiap narapidana. ${ }^{5}$

Menurut Meilina (2013) dampak psikologis pada narapidana banyak dialami oleh narapidana pada awal masa pidana. Hal tersebut dikarenakan narapidana membutuhkan waktu untuk 'nenyesuaikan diri dengan lingkungan baru dan tata tertib baru yang terdapat dl dalam Lembaga Pemasyarakatan.

Oleh karena itu upaya pemenuhan dan perlindungan HAM bagi narapidana perempuan seharusnya tidak hanya sekadar diwujudkan dalam bentuk undang -undang atau kebijakan saja, tetapi juga seharusnya diwujudkan dalam bentuk implementasi dan

\footnotetext{
${ }^{4}$ https://suaraindonesianews.com/news/puluhan-tahanan-kabur-dari-rutan-lhoksukon-aceh-utara/

${ }^{5}$ Meilina, 2013 “dampak psikologis bagi narapidana wanita yang melakukan tindak pidana pembunuhan dan upaya penanggulangannya
} 
pemenuhan atas hak - hak oleh petugas di dalam Lembaga Pemasyarakalan Perempuan tersebut. Sehingga pada penulisan ini bertujuan untuk menggambarkan impelementasi perlindungan HAM narapidana perempuan pada lembaga pemasyarakatan Adapun tujuan penelitian ini adalah:

Penelitian ini mengunakan metode kualitatif yang bersifat deskriptif dengan pengambilan data menggunakan studi pustaka (library research) dengan jenis penelitian hukum normatif, yaitu penelitian yang mengkaji mengenai asas - asas hukum, sistematika hukum, taraf sinkronisasi hukum ${ }^{6}$. Penelitian terhadap asas - asas hukum dilakukan terhadap kaidah - kaidah hukum yang merupakan patokan berperilaku atau bersikap tidak pantas. Penelitian tersebut dapat dilakukan ( terutama) terhadap bahan hukum primer dan sekunder.

Sumber data yang digunakan Sumber data yang digunakan oleh penulis dalam penelitian ini adalah sumber data sukender. Adapun data sukunder di dalam penelitian ini dapat dibedakan menjadi 2, yaitu:

a. Bahan Hukum Primer, yaitu bahan hukum yang mengikat yang dapat terdiri:

1) Undang - Undang Dasar Republik Indonesia Tahun 1945

2) Undang - Undang Nomor 12 Tahun 1995 tentang Pemasyarakatan

3) Undang - Undang Nomor 39 Tahun 1999 tentang Hak Asasi Manusia

4) Peraturan Pemerintah Nomor 99 Tahun 2012 Tentang perubahan kedua atas Peraturan pemerintah Nomor 32 Tahun 1999 tentang syarat dan Tata cara pelaksanaan Hak Warga Binaan Pemasyarakatan.

b. Bahan Hukum sekunder, Yaitu bahan hukum yang memberi penjelasan mengenai bahan hukum primer, misalnya:

1) Buku - buku literature yang berhubungan dengan Perlindungan HAM

2) Artikel/Skripsi/Karya tulis ilmiah mengenai Perlindungan narapidana

3) buku- buku mengenai sistem pembinaan narapidana

\section{HASIL DAN PEMBAHASAN}

\section{Implementasi Perlindungan HAM bagi Narapidana Perempuan di Lapas/Rutan}

Untuk mengetahui gambaran implementasi HAM narapidana perempuan di Lapas / Rutan dapat dibagi menjadi 12 kriteria sesuai hak - hak yang di dapatkan narapidana yang bersifat bersyarat dan bersifat absolut.

- Melaksanakan ibadah sesuai agama dan kepercayaan

- Mendapatkan perawatan jasmani dan rohani

- Mendapatkan program pendidikan dan pengajaran yang layak

- Mendapatkan pelayanan kesehatan medis yang layak

- Mendapatkan layanan psikologi yang layak

- Mendapatkan makanan yang layak

${ }^{6}$ Soekanto.S, 2001, pengantar penelitian hukum Normatif. Bandung, 
- Mendapatkan layanan bimbingan sipiritual/keagamaan yang layak

- Menyampaikan keluhan

- Mendapatkan siaran media massa dan layanan bahan bacaan

- Mendapatkan upah atas kerajinan tangan yang dilakukan

- Mendapatkan kunjungan dari keluarga dan orang tertentu lainnya

- Mendapatkan kesempatan berasimilasi, cuti dan mengunjungi keluarga

Berdasarkan Tabel di bawah ini:

Tabel. 1

Implementasi Hak-Hak Narapidana

Sumber Data: Balitbangda ( Badan Penelitian dan Pengembangan Daerah), $2014^{7}$

\begin{tabular}{|c|c|c|c|c|}
\hline \multirow[t]{2}{*}{ NO. } & \multirow[t]{2}{*}{ ITEM } & \multicolumn{2}{|c|}{ PILIHAN } & \multirow[t]{2}{*}{ KATEGORI } \\
\hline & & YA & TIDAK & \\
\hline 1. & $\begin{array}{l}\text { Menjalankan ibadah } \\
\text { sesuai agama dan } \\
\text { kepercyaan }\end{array}$ & $253(98,4 \%)$ & $4(1,6 \%)$ & TINGGI \\
\hline 2. & $\begin{array}{l}\text { Perawatan jasmani dan } \\
\text { rohani }\end{array}$ & $249(96,9 \%)$ & $8(3,1 \%)$ & TINGGI \\
\hline 3. & $\begin{array}{l}\text { Pendidikan dan } \\
\text { pengajaran yang layak }\end{array}$ & $60(23,3 \%)$ & $197(76,7 \%)$ & RENDAH \\
\hline 4. & $\begin{array}{l}\text { Pelayanan kesehatan dan } \\
\text { medis }\end{array}$ & $235(91,4 \%)$ & $22(8,6 \%)$ & TINGGI \\
\hline 5. & Layanan psikologi & $101(36,3 \%)$ & $156(64,7 \%)$ & RENDAH \\
\hline 6. & Layanan makanan & $252(98,4 \%)$ & $5(1,6 \%)$ & TINGGI \\
\hline 7. & $\begin{array}{l}\text { Layanan bimbingan dan } \\
\text { spiritual keagamaan }\end{array}$ & $105(40,9 \%)$ & $152(59,1 \%)$ & RENDAH \\
\hline 8. & $\begin{array}{l}\text { Penyampaian keluhan } \\
\text { kepada petugas }\end{array}$ & $202(78,6 \%)$ & $55(21,4 \%)$ & TINGGI \\
\hline 9. & $\begin{array}{l}\text { Layanan bahan bacaan } \\
\text { dan siaran media }\end{array}$ & $247(96,1 \%)$ & $11(3,9 \%)$ & TINGGI \\
\hline 10. & $\begin{array}{l}\text { Mendapatkan upah atas } \\
\text { kerajinan tangan }\end{array}$ & $114(44,4 \%)$ & $143(55,6 \%)$ & RENDAH \\
\hline 11. & $\begin{array}{l}\text { Waktu luang menerima } \\
\text { kunjungan keluarga dan } \\
\text { orang tertentu lainnya }\end{array}$ & $245(95,3 \%)$ & $12(4,7 \%)$ & TINGGI \\
\hline 12. & $\begin{array}{l}\text { Mendapatkan } \\
\text { kesempatan asimilasi, } \\
\text { cuti dan mengunjungi } \\
\text { keluarga }\end{array}$ & $60(23,3 \%)$ & $197(76,7 \%)$ & RENDAH \\
\hline
\end{tabular}

\footnotetext{
${ }^{7}$ Balitbangda (Badan Penelitian dan Pengembangan Daerah), 2014, "studi penelitian narapidana perempuan di Sulawesi
} selatan" Makassar. 
Dari data diatas dapat disimpulkan bahwa dari dua belas item kriteria perlindungan HAM pada narapidana perempuan di Lapas/Rutan, terdapat 5 item yang pada implementasinya masih tergolong rendah dan harus mendapatkan perbaikan, yaitu:1) Pendidikan dan pengajaran yang layak, 2) pemberian bantuan dan layanan psikologi, 3) pemberian bimbingan spiritual/keagamaan, 4) mendapatkan upah atas kerajinan tangan, dan 5) kesempatan berasimilasi termasuk mendapat kunjungan keluarga.

Adapun ketujuh kriteria implementasi perlindungan HAM bagi narapidana perempuan yang sudah berjalan baik adalah: 1) melakukan ibadah sesuai dengan agama dan kepercayaan, 2) perawatan jasmani, 3) mendapatkan pelayanan kesehatan medis yang layak, 4) mendapatkan makanan yang layak, 5) menyampaikan keluhan, 6) mendapakatkan bahan bacaan dan 7) diberikan waktu luang menerima kunjungan dari keluarga atau orang tertentu lainnya.

2. Kondisi Sarana dan Prasarana Lembaga Pemasyarakatan / RUTAN

Berdasarkan hasil observasi mengenai keadaan sarana dan prasarana Lapas/Rutan, maka dapat diketahui seperti table dibawah ini:

Tabel 2

Keadaan Sarana dan Prasarana Lapas / Rutan

\begin{tabular}{|c|c|c|c|c|c|c|}
\hline \multirow[t]{2}{*}{ NO } & \multirow[t]{2}{*}{ SARANA DAN PRASARANA } & \multicolumn{4}{|c|}{ KEADAAN } & \multirow[t]{2}{*}{ KETERANGAN } \\
\hline & & SB & $\mathrm{B}$ & $\mathrm{BKB}$ & STB & \\
\hline 1. & $\begin{array}{l}\text { Fasilitas ibadah } \\
\text { (Masjid, gereja) }\end{array}$ & & $\mathrm{X}$ & & & \\
\hline 2. & $\begin{array}{c}\text { Fasilitas Kesehatan } \\
\text { (obat - obatan, klinik, p3k,dll) }\end{array}$ & & $\mathrm{X}$ & & & $\begin{array}{l}\text { Persediaan } \\
\text { terbatas }\end{array}$ \\
\hline 3. & Fasilitas Olahraga & & $\mathrm{X}$ & & & \\
\hline 4. & $\begin{array}{c}\text { Fasilitas Pelatihan/ketrampilan } \\
\text { (mesin jahit, bengkel, memasak, } \\
\text { bahan kerajinan tangan) }\end{array}$ & & $\mathrm{X}$ & & & \\
\hline 5. & $\begin{array}{c}\text { Fasilitas lainnya } \\
\text { (ruangan kunjungan, kantin, } \\
\text { wartel, dll) }\end{array}$ & & $\mathrm{X}$ & & & \\
\hline
\end{tabular}

Sumber Data: Balitbangda ( Badan Penelitian dan Pengembangan Daerah), 2014

Hasil observasi diatas menunjukan bahwa pada 5 item Sarana dan prasarana dalam Lembaga Pemasyarakatan dalam keadaan baik. Namun demikian sarana dan prasarana tersebut sangat terbatas jika dibandingkan dengan jumlah penghuni di dalamnya. Seperti pada contoh Lembaga Pemasyarakatan Perempuan klas IIA Jakarta Timur.

\section{Faktor pendukung dan penghambat implementasi perlindungan HAM narapidana} perempuan pada Lapas/Rutan

Berdasarkan hasil wawancara dengan informan petugas Lapas/Rutan yaitu MA Kepala Sub Seksi Registrasi Lapas Perempuan klas IIA Jakarta timur mengenai faktor pendukung dan penghambat dalam implementasi HAM narapidana perempuan, adapun faktor -faktor yang dimaksud sebagai berikut: 
1. Anggaran

Menurut MA anggaran merupakan faktor utama dalam mendukung berjalannya program pembinaan dan kemandirian narapidana. Seperti dalam menyediakan bahan - bahan kebutuhan peralatan, perlengkapan dan kebutuhan sehari - hari seperti untuk makan narapidana. Berbagai program pembinaan yang lain seperti program kesenian, kerajinan tangan, paduan suara, ketrampilan dan lain - lain yang sangat memerlukan anggaran yang ideal bagi lapas tersendiri. Sehingga kendala selama ini yaitu terbatasnya anggaran UPT dari kanwil setempat. ${ }^{8}$

2. Sumber Daya Manusia (petugas)

Tenaga dan sumber daya yang tersedia di lembaga pemasyarakatan dirasakan masih perlu ditingkatkan kualitas dan kuantitasnya. Secara kuantitas pemerintah seharusnya menambahkan lagi petugas pemasyarakatan, terutama dibidang keamanan yang dirasa masih belum ideal. Dan secara kualitas para petugas tersebut harus diberi pelatihan lebih lanjut agar dapat membantu proses penyelenggaraan pembinaan secara optimal.

3. Karakter narapidana

Menurut MA bahwa karakter narapidana perempuan sangat berbeda - beda. Mereka semuanya orang - orang bermasalah. Kondisi seperti ini diperlukan ketrampilan extra untuk menangani perbedaan karakter tersebut. Namun demikian jika mereka semua sudah terlatih selama di dalam lapas, maka mereka dapat membantu dan berkerja sama satu sama lain untuk mengembangkan program - program pembinaan

4. Sarana dan prasarana

Sarana dan prasarana yang terbatas membuat Lapas/Rutan kesulitan dalam hal implementasi program - program pembinaan. Terlebih lagi lokasi yang berdekatan dengan Rutan perempuan yang hanya dibatasi dengan jarring membuat semakin terbatas sarana dan prasarana yang ada. Namun demikian pembinaan tetap dijalankan secara optimal, dengan memanfaatkan sarana dan prasarana yang tersedia

5. Kerjasama dengan lembaga lain

Untuk mendukung program - program pembinaan dari berbagai aspek sebagai implementasi perlindungan dan pemenuhan HAM narapidana perempuan, maka dibutuhkan dukungan, perhatian dan kepedulian dari lembaga - lembaga terkait, seperti contohnya pemerintah kota dan provinsi. Pihak Lapas dan Rutan kesulitan dalam hal seperti: pendidikan dan pengajaran, terapi psikologi, dan lain - lain. Oleh karena itu kerja sama dengan lembaga lain sangat dibutuhkan

Berdasarkan data hasil penelitian menunjukkan bahwa implementasi perlindungan HAM narapidana perempuan di Lembaga pemasyarakatan/Rutan ternyata dari dua belas item kriteria Implementasi perlindungan HAM yang diedarkan kepada narapidana, terdapat lima kriteria implementasi perlindungan HAM pada narapidana perempuan yang helum berjalan secara opiimal, yaitu: a) pendidikan dan pengajaran yang layak. b) pemberian bantuan dan layanan psikologi, c) pemberian bimbingan lanjutan

${ }^{8}$ Rachmayanty, 2017 “impelementasi penganggaran berbasis kinerja dalam menunjang tugas dan fungsi pemasyarakatan” Jakarta. 
spiritual/keagamaan, d) mendapatkan upah atas kerajinan tangan yang dilakukan, dan e) mendapatkan kesempatan berasimilasi ternrasuk cuti dan mengunjungi keluarga.

Adapun ketujuh kriteria imptementasi perlindungan HAM bagi narapidana perempuan yang sudah berjalan dengan baik adalah: a) melakukan ibadah sesuai dengan agama dan kepercayaan, b) perawatan jasmani, c) rnendapatkan pelayanan kesehatan medis yang layak, d) mendapatkan layanan makanan yang layak, e) menyampaikan keluhan kepada petugas, f) bahan bacaan dan mengikuti siaran media massa lainnya, serta g) diberikan waktu luang menerima kunjungan keluarga, penasihat hukum atau orang tertentu lainnya.

Terkait dengan hal tersebut, maka kelima kriteria implementasi perlindungan HAM bagi narapidana perempuan perlu mendapatkan perhatian agar perlindungan HAM bagi narapidana perempuan dapat berjalan secara optimal. Walau bagaimanapun perlindungan HAM bagi narapidana merupakan hak - hak mereka yang sepatutnya harus di dapatkan seperti yang di amanahkan dalam UU RI no. 12 tahun 1995 Tentang Pemasyarakatan. Soetandyo (2012) menyebutkan bahwa HAM bersifat universal karena hak - hak tersebut dinyatakan sebagai bagian dari kemanusiaan apapun warna kulit, jenis kelamin, usia, latar belakang budaya, agama atau kepercayaannya. HAM dikatakan melekat dan inheren karena hak-hak tersebut dimiliki setiap manusia semata-mata karena keberadaannya sebagai manusia dan bukan karena pemberian dari suatu organisasi kekuasaan manapun. HAM sifatnya melekat karena hak-hak yang dimiliki manusia tidak dapat dirampas dan dicabut.3 Dalam konteks ini sifat HAM yang melekat dan inheren pada setiap manusia menghendaki tidak adanya institusi kekuasaan atau siapapun yang diperbolehkan merampas dan mencabutnya kecuali adanya alasan kemanusiaan yang rasional dan absah menurut hukum. ( Pusat Studi Hak Asasi Manusia Surabaya).

Implementasi perlindungan HAM tidak berjalan secara optimal jika tidak di dukung dengan sarana dan prasarana Lapas yang baik. Pada analisis data sarana dan prasarana pada Lapas perempuan Jakarta timur sudah menunjang dengan baik. Meskipun demikian perlu adanya penambahan fasilitas. Misalnya perluasan area Lapas Perempuan klas IIA Jakarta, yang pada saat ini hanya disekat dan berdekatan dengan Rutan perempuan Jakarta timur. Walaupun kondisinya sudah baik, namun penyediaan sel tahanan terasa kurang karena jumlah tahanan dan kapasitas Lapas tidak berimbang.

Implementasi perlindungan HAM bagi narapidana perempuan akan berjalan dengan baik jika didukung oleh beberapa hal seperti: Penyediaan anggaran yang cukup untuk menjalankan program - program dan dapat di salurkan tepat waktu. Bagaimanapun anggaran merupakan modal yang sangat penting dalam mendukung terlaksananya program - program pembinaan di Lembaga Pemasyarakatan. Disamping itu petugas lapas dituntut professional dalam melaksanakan tugas dan bertanggung jawab dalam membina narapidana seperti yang di amanahkan undang - undang.

Hal lain yang turut mendukung terlaksananya perlindungan HAM bagi narapidana perempuan adalah ketersediaan sarana dan prasarana baik pembinaan, pendidikan, maupun ketrampilan. Demikian pula halnya karakteristik dan kepribadian narapidana. Sehingga tenaga psikolog, rohaniawan dan tenaga pengajar diperlukan kehadirannya dalam lapas untuk melakukan pembinaan bagi narapidana. 


\section{PENUTUP}

Berdasarkan hasil penelitian dan pembahasan, dapat di tarik suatu kesimpulan antara lain:

1) Implementasi perlindungan HAM narapidana perempuan di Lapas Perempuan klas IIA Jakarta timur belum berjalan secara optimal. Ada lima aspek kriteria yang perlu mendapatkan perhatian khusus yaitu: a) pendidikan dan pengajaran yang layak. b) pemberian bantuan dan layanan psikologi, c) pemberian bimbingan lanjutan spiritual/keagamaan, d) mendapatkan upah atas kerajinan tangan yang dilakukan, dan e) mendapatkan kesempatan berasimilasi termasuk cuti dan mengunjungi keluarga.

2) Sarana dan prasarana Lembaga Pemasyarakatan masih perlu dilakukan penambahan dan perluasan area

3) Ada lima aspek yang menjadi pendukung dan penghambat implementasi perlindungan HAM narapidana perempuan, yaitu: Anggaran, Sumber daya manusia ( petugas ), Karakter narapidana, kerja sama lembaga lain

\section{DAFTAR PUSTAKA}

\section{Buku}

Ahmad, Ahmad \& Alwi, M. Ahkam., dll,2014, Studi Penelitian Narapidana Perempuan di Sulawesi Selatan Makassar. Balitbangda: Makasar

Soekanto.S, 2001, Pengantar Penelitian Hukum Normatif. Rajawali Pers :Bandung

\section{Artikel}

Meilina, 2013 "Dampak Psikologis Bagi Narapidana Wanita Yang Melakukan Tindak Pidana Pembunuhan Dan Upaya Penanggulangannya. Jurnal Hukum : Universitas Brawijaya , diakses melalui website hukum.studentjournal.ub.ac.id

Rachmayanty, 2017, Impelementasi Penganggaran Berbasis Kinerja Dalam Menunjang Tugas dan Fungsi Pemasyarakata. Jurnal UNPAM : Universitas Pamulang, diakses melalui website openjournal.unpam.ac.id

\section{Perundang - Undangan}

Undang - Undang Nomor 39 Tahun 1999 Tentang Hak Asasi Manusia Bab 1 Memuat Ketentuan Umum

Undang - Undang Nomor 12 tahun 1995 Tentang Pemasyarakatan Pasal 14 Memuat Aspek Aspek Hak Narapidana

Peraturan Pemerintah Nomor 99 Tahun 2012 Tentang Perubahan Kedua Atas Peraturan Pemerintah Nomor 32 Tahun 1999 Tentang Syarat dan Tata Cara Pelaksanaan Hak 
